\title{
Transport and reaction of iron and iron stable isotopes in glacial meltwaters on Svalbard near Kongsfjorden: From rivers to estuary to ocean.
}

Ruifeng Zhang a, ${ }^{\mathrm{a}}$, Seth G. John ${ }^{\mathrm{b}}$, Jing Zhang ${ }^{\mathrm{a}}$, Jingling Ren ${ }^{\mathrm{c}}$, Ying Wu ${ }^{\mathrm{a}}$, Zhuoyi Zhu ${ }^{\mathrm{a}}$, Sumei Liu ${ }^{\mathrm{c}}$, Xunchi Zhu ${ }^{\mathrm{a}}$, Chris M. Marsay ${ }^{\mathrm{b}}$, Fred Wenger ${ }^{\mathrm{d}}$

a State Key Laboratory of Estuarine and Coastal Research, East China Normal University, Shanghai 200062, China

b Department of Earth and Ocean Sciences, University of South Carolina, Columbia, SC 29208, USA

c Key Laboratory of Marine Chemistry Theory and Technology, Ministry of Education, Ocean University of China, Qingdao 266100, China

d Norwegian Water Resources and Energy Directorate, Middelthunsgate 29, Postboks 5091 Majorstua, 0301 Oslo, Norway

* Corresponding author.

Address: State Key Laboratory of Estuarine and Coastal Research, East China Normal University, Shanghai 200062, China

Telephone: +86-21-62233890

E-mail address: rfzhang@sklec.ecnu.edu.cn (R. Zhang). 


\section{ABSTRACT}

1 Glacial meltwater has been suggested as a significant source of potentially

2 bioavailable iron to the oceans. However, the supply of dissolved iron $(\mathrm{dFe})$ in glacial

3 meltwaters is poorly constrained as few sites have been studied, and because the

4 chemical processing of Fe during transport from glaciers to the adjacent coastal ocean

5 is not well understood. In order to better constrain glacial fluxes of dFe to the ocean,

6 iron concentrations, iron stable isotopes $\left(\delta^{56} \mathrm{Fe}\right)$, and other supporting chemical and

7 physical measurements were made along a $\sim 4 \mathrm{~km}$ long glacial meltwater river on

8 Svalbard and in estuarine waters that it flows into. Dissolved iron concentrations in

9 the Bayelva River decreased from a maximum of $734 \mathrm{nM}$ near the glacier to an

10 average value of $116 \mathrm{nM}$ near the mouth of the river. Measurements in the

11 Kongsfjorden estuary suggest that 3 to $10 \mathrm{nM}$ of dFe from the Bayelva River is

12 stabilized in glacial waters by the time it mixes into the ocean. Incubation of Bayelva

13 River waters over two weeks in both the light and dark show similar results, with the

14 majority of $\mathrm{dFe}$ being quickly precipitated and 4 to $7 \mathrm{nM} \mathrm{Fe}$ stabilized in the

15 dissolved phase. Evidence suggests that $\mathrm{Fe}$ is most likely lost from the dissolved

16 phase by aggregation and adsorption of nanoparticulate and colloidal Fe to particles.

17 Dissolved $\delta^{56} \mathrm{Fe}$ was between $-0.11 \%$ and $+0.09 \%$ for all river samples and did not

18 vary systematically with $\mathrm{dFe}$ concentrations. We infer that the Fe is lost from the

19 dissolved phase by a process that fractionates Fe isotopes by less than $0.05 \%$,

20 indicating that the Fe bonding environment does not change during precipitation. This 
21 is consistent with DOC loss that is much faster than predicted photo-oxidation rates,

22 suggesting that DOC is also lost through adsorption and precipitation. Dissolved Fe

23 concentrations in the Bayelva River (15-734 nM), and Fe concentrations which are

24 stabilized in the dissolved phase (4-7 $\mathrm{nM}$ ) are much lower than some previous

25 estimates of Fe in glacial meltwaters, with roughly $80 \%$ of dFe lost during transit in

26 the Bayelva River and roughly $90 \%$ of the remaining dFe lost in the estuary. This may

27 mean that glaciers are a less significant source of dissolved Fe to the global oceans

28 than has been previously hypothesized, that cold base glaciers of the type studied here

29 do not contribute significantly to the dissolved Fe flux, or that the flux of reactive

30 particulate $\mathrm{Fe}$ to the oceans is more important than the dissolved flux. In Arctic

31 regions with similar proglacial environments, bedrock composition, weathering

32 intensity, and as precipitation of colloidal and nanoparticulate Fe may all play an

33 important role in regulating the glacial meltwater iron flux to the ocean.

34

35 Keywords: Arctic; glacier; meltwater; dissolved iron; iron isotopes 


\section{Introduction}

Despite the high abundance of Fe in the earth's crust ( $\sim 5 \%)$, concentrations of Fe

39 in the modern oxidized oceans are very low (typically $<1 \mathrm{nM}$ in the open ocean) due to the low solubility of Fe in seawater (Bruland and Lohan, 2003). Low Fe

41 concentrations, combined with physiological requirement for Fe by phytoplankton for

42 processes such as photosynthesis and nitrogen fixation, means that $\mathrm{Fe}$ is the limiting

43 nutrient for phytoplankton growth in much of the surface ocean (Moore et al., 2002).

44 The residence time of $\mathrm{Fe}$ in seawater is much shorter than the timescale of ocean

45 circulation (e.g. Moore et al 2004; Parekh et al., 2004), meaning that Fe

46 concentrations in the ocean are highly dependent on local sources and sinks of the

47 element. Deposition of dust transported from the continents has often been considered

48 the most important source of Fe to the remote oceans (Jickells et al., 2005), though

49 continental-margin sediments (Elrod et al., 2004; Lam and Bishop, 2008) and

50 hydrothermal vents (Saito et al., 2013; Tagliabue et al., 2010) may also represent

51 important sources of biologically available Fe. Recently, glacial Fe inputs in the form

52 of icebergs and glacial meltwater have been proposed as significant sources of

53 bioavailable iron to the ocean (e.g. Bhatia et al., 2013; Death et al., 2014; Smith et al.,

54 2007). As the rate of glacial melting increases due to climate change, this flux of

55 glacial $\mathrm{Fe}$ to the oceans may increase, potentially providing an important climate 56 feedback. 

iceberg calving, delivers both dissolved $\mathrm{Fe}(\mathrm{dFe})$ and particulate $\mathrm{Fe}$ to the high-latitude oceans. Dissolved soluble Fe species are typically considered bioavailable, and very small Fe particles within the colloidal $(0.02-0.45 \mu \mathrm{m})$ or

61 nanoparticulate $(0.02-1 \mu \mathrm{m})$ size range, which can be produced in the glacial environment, are also thought to provide bioavailable Fe because they are more soluble and reactive than larger particles (Raiswell, 2011). Similarly, free drifting icebergs may release iron to support primary production (Smith et al., 2007). These findings have implications for global productivity because Fe is a limiting nutrient throughout the Southern Ocean and large parts of the subarctic Pacific, and there is evidence that Fe may also limit the extent of seasonal nutrient drawdown in the high latitude North Atlantic (Achterberg et al., 2013; Boyd et al. 2007, Nielsdottir et al 2009). Recently, field observations have supported the idea that glacial Fe is

70 bioavailable by showing that it supports a phytoplankton bloom along a glacier 71 meltwater plume in the Amundsen Sea (Gerringa et al., 2012). Despite the possible importance of glacial Fe, dissolved Fe supply from glacial

73 meltwaters is poorly constrained due to the limited number of measurements and the 74 great variability in $\mathrm{dFe}$ concentrations in these few samples. For example, 75 concentrations of up to $9,950 \mathrm{nM}$ were observed at a location in Greenland, leading to 76 an estimated annual flux of biologically available Fe from Greenland meltwater which 77 is comparable to dust-derived soluble iron inputs to the North Atlantic (Bhatia et al., 
2013). Just $100 \mathrm{~km}$ to the south in Greenland, however, Statham et al. (2008) observed glacial meltwater with an average dFe concentration of $52 \mathrm{nM}$. At a location $30 \mathrm{~km}$ further south at the Leverett Glacier, soluble iron $(<0.02 \mu \mathrm{m})$ concentrations in meltwater averaged $7 \mathrm{nM}$, however, iron concentrations in the colloidal size range $(0.02-0.45 \mu \mathrm{m})$ spanned an order of magnitude, from $232 \mathrm{nM}$ to $4701 \mathrm{nM}$ (Hawkings et al., 2014). understanding the chemical processing of glacial Fe. Glacial meltwater runoff is characterized by a high physical to chemical erosion ratio (Raiswell et al., 2006), oxygen depletion in the subglacial environment (Hodson et al., 2002), and often by the presence of proglacial basins. Much of the glacial particulate Fe load is in the form of nanoparticulate Fe oxyhydroxides, which have been hypothesized to be directly or indirectly bioavailable, and which may be more easily solubilized in seawater (Raiswell et al., 2006; Raiswell et al., 2009; Raiswell, 2013). Indeed, glacial meltwaters in western Greenland were found having a much higher percentage of $\mathrm{dFe}$

93 in the colloidal fraction (>98\%) (Hawkings et al., 2014) than typical non-glacial rivers 94 (e.g. Dai et al., 1995; Escoube et al., 2009; Stolpe et al., 2010). Glacial fed tributaries 95 of the Copper River, Alaska, which were shown to have a higher sediment load than 96 other types of tributaries, also had much higher colloidal Fe concentrations (Schroth 97 et al., 2011). 
99 biogeochemical cycling of $\mathrm{Fe}$ in rivers and the marine environment, though they have

100 so far been minimally applied to the study of glacial systems. The total observed

101 range in riverine $\delta^{56} \mathrm{Fe}$ is between -1.2 and $+2.8 \%$, with variations dependent both on

102 river chemistry and filter pore size (e.g. Ilina et al., 2013; Schroth et al., 2011).

103 Continental weathering has been inferred to preferentially release light Fe into the

104 riverine dissolved phase under some conditions (Fantle and DePaolo, 2004). However,

105 the amount of dissolved organic material can also be important in determining $\delta^{56} \mathrm{Fe}$.

106 For example, $\delta^{56} \mathrm{Fe}$ values of $-0.2 \pm 0.1 \%$ were measured for $\mathrm{dFe}$ in main channel sites

107 of the Amazon River (Bergquist and Boyle, 2006), while isotopically heavy dFe

$108(+0.30 \%)$ was measured in waters of an organic-rich tributary. Positive values of

109 dissolved $\delta^{56} \mathrm{Fe}$ have also been reported for the North River, in the United States

110 (Escoube et al., 2009), and some boreal rivers in Russia (Ilina et al., 2013). Recent

111 work on a glacial river showed that the isotopic signature of dFe was found to be

112 similar to crustal values in a glacier fed tributary of the Copper River (Schroth et al.,

113 2011). Better constraints on the $\delta^{56} \mathrm{Fe}$ of dissolved and particulate $\mathrm{Fe}$ in glacial

114 meltwaters may make it possible to use Fe isotopes to trace the global distribution of

115 glacial Fe in the oceans, as has recently been done for other Fe sources to the North

116 Atlantic (Conway and John, 2014).

117 The aim of this study is to investigate the transportation and transformation of

$118 \mathrm{dFe}$ between a glacial source and the ocean, via a glacial meltwater river. In addition

119 to measurements of $\mathrm{dFe}$ concentration and $\delta^{56} \mathrm{Fe}$, ancillary parameters including 
120 dissolved oxygen (DO), dissolved Mn (dMn), dissolved organic carbon (DOC), total

121 suspended matter (TSM), and $\mathrm{pH}$ were measured. These data are used to better

122 understand the chemical cycling of glacial Fe in the Bayelva River, and to refine

123 estimates of glacial Fe delivery to the ocean.

124

125 2. Materials and methods

$126 \quad 2.1$ Study area

127 Sampling for this study was performed in the vicinity of the Ny-Ålesund

128 International Research Facility next to Kongsfjorden, Svalbard (Fig. 1). Svalbard is

129 located in the southern portion of the Arctic Ocean, at the northern end of the

130 Greenland Sea. The region is an important site of North Atlantic Deep Water (NADW)

131 formation, warm North Atlantic waters travel along the western coast of Svalbard

132 before sinking to form NADW (Jungclaus et al., 2005). 


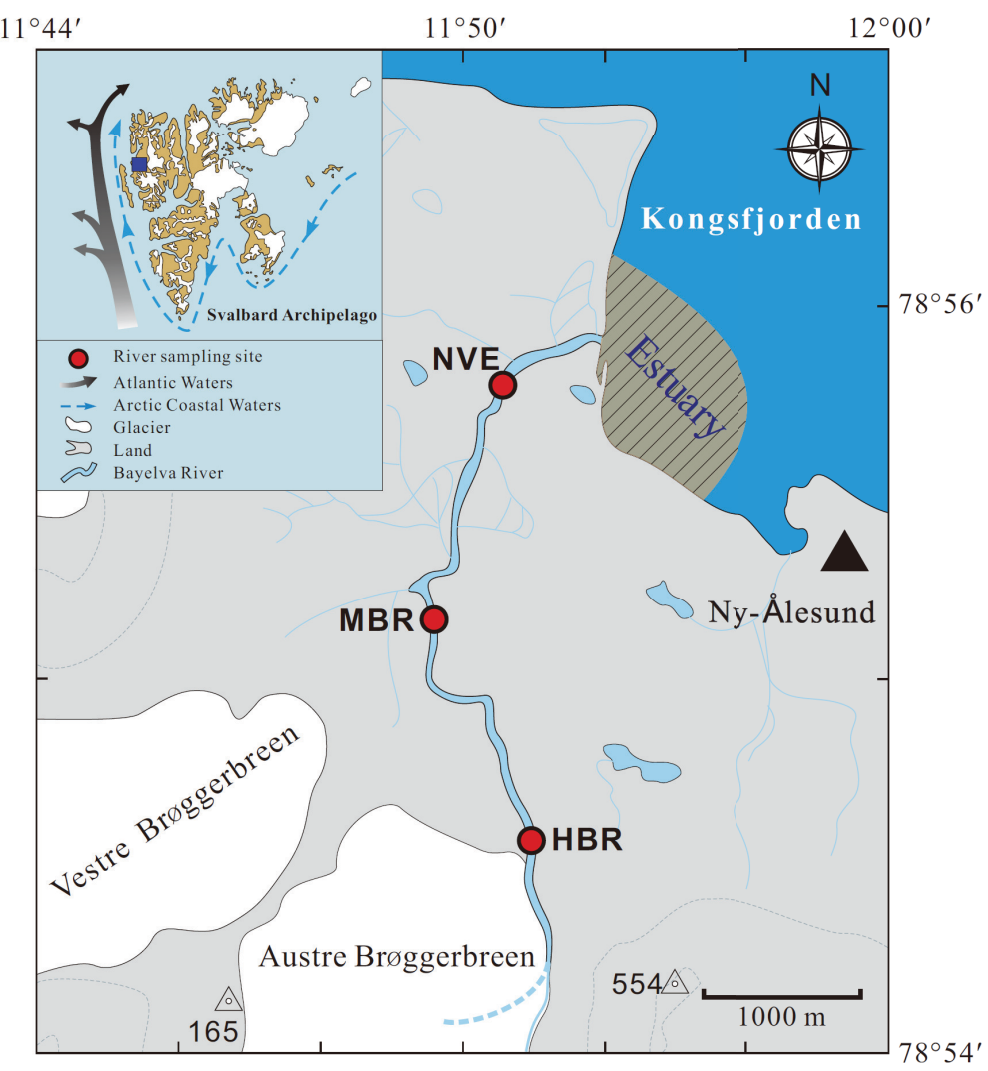

134 Fig. 1. Map of the study area, with the Bayelva River flowing from supraglacial terrain of the Austre

About $60 \%$ of the land in the Svalbard archipelago is covered by glaciers, with

141 estimated fluxes of meltwater and iceberg calving of $25 \pm 5 \mathrm{~km}^{3} \mathrm{a}^{-1}$ and $4 \pm 1 \mathrm{~km}^{3} \mathrm{a}^{-1}$,

142 respectively (Hagen et al., 2003). The Bayelva River, which this study focuses on, is

143 approximately $4 \mathrm{~km}$ long, with a catchment area of $32 \mathrm{~km}^{2}$, of which $50 \%$ is glaciated

144 by the cold-based valley glaciers Austre and Vestre Brøggerbreen, both of which have

145 thicknesses less than $100 \mathrm{~m}$ (Krawczyk et al., 2003). Although meltwater from 
cold-based glaciers is not typically thought to have subglacial drainage flowpaths, the water chemistry in Bayelva River at the end of ablation season, when our sampling occurred, was found to be similar to that of subglacial meltwaters (Nowak and Hodson, 2014). The Bayelva River catchment is bounded by steep mountain ridges to

150 the south and the Kongsfjorden fjord to the north. The annual discharge of the river is

151 estimated to be $\sim 30 \cdot 10^{6} \mathrm{~m}^{3}$ (Hagen et al., 2003), with suspended sediment transport of 152 between $5.1 \cdot 10^{9}$ to $22.8 \cdot 10^{9}$ g per year (Bogen and Bonsnes, 2003).

153 Sampling expeditions were carried out in August 2012 and 2013. Sampling 154 locations along the Bayelva River were the HBR (head of Bayelva River) site, near 155 the Austre Brøggerbreen glacier and $\sim 0.5 \mathrm{~km}$ downstream from the visible 156 supraglacial output, the MBR (middle-reach of Bayelva River) station located in the 157 middle reach of Bayelva River, $\sim 1.8 \mathrm{~km}$ from glacier, and the NVE (Norwegian 158 Water Resources and Energy Directorate) station situated $2 \mathrm{~km}$ northwest of $159 \mathrm{Ny}-$ Ålesund and $300 \mathrm{~m}$ from the outlet of the Bayelva River into Kongsfjorden. All 160 three locations were sampled at least once during both the 2012 and 2013 campaigns, 161 and the NVE site was sampled 5 times during 2012. The Bayelva River estuary was 162 sampled only during 2012.

163

\section{$164 \quad 2.2$ Sample collection and handling}

165 All plasticware, including high density polyethylene (HDPE) bottles (Nalgene) 166 and Teflon PFA filtration assemblies (Savillex) were cleaned in a class 1000 clean lab 

2\% Citranox detergent for 24 hours, rinsing five to seven times with ultrapure water,

169 leaching for 7 days in $10 \% \mathrm{HCl}$ at room temperature or for 2 days in $10 \% \mathrm{HCl}$ at 60

$170{ }^{\circ} \mathrm{C}$, and rinsing again five times with ultrapure water. In addition to the cleaning steps

171 described above, PFA was boiled in 10\% aqua regia for $30 \mathrm{~min}$ before Citranox and $17210 \% \mathrm{HCl}$ cleaning steps. HDPE bottles were filled with $0.1 \%(0.012 \mathrm{M}) \mathrm{HCl}$ using 173 acid purified by quadruple distillation in a quartz still (QD $\mathrm{HCl}$ ), and sealed in double 174 bags until use. Filters (0.4 $\mu \mathrm{m}$ PC membranes, Whatman) were cleaned in $10 \%$ QD $175 \mathrm{HCl}$ at $60^{\circ} \mathrm{C}$ for 24 hours, rinsed ten times with ultrapure water, cleaned at $60{ }^{\circ} \mathrm{C}$ for 176 another week in ultrapure water, then rinsed five times with ultrapure water.

177 Water samples were collected using a custom made "pole sampler" consisting of 178 a PVC holder attached to the end of a fishing rod. This $2 \mathrm{~m}$ long rod made it possible 179 to avoid contamination from the side of the ship when sampling in Kongsfjorden, and 180 allowed samples to be taken from the middle of the main stream of the Bayelva River.

181 To collect samples, a 1 L HDPE bottle was attached to the pole sampler, rinsed 182 several times with the natural waters, and submerged until full. After sampling, 183 bottles were sealed and stored in double plastic bags in a dark cool box until filtration 184 in an onshore lab in Ny-Ålesund.

185 Samples were filtered through a $0.4 \mu \mathrm{m}$ pore size membrane, meaning our 186 samples included both soluble Fe $(<0.02 \mu \mathrm{m})$ and colloidal Fe as typically defined 187 operationally in the chemical oceanography literature $(0.02-0.45 \mu \mathrm{m})(\mathrm{Wu}$ et al., 
2001). These samples will also include a portion of the Fe occurring in the size range typically described as nanoparticulate $(0.02-0.1 \mu \mathrm{m})$ (Raiswell and Canfield, 2012). Samples were filtered in a class 100 portable clean flow bench (Air Control). The filtration system was rinsed with copious quantities of $0.1 \%$ QD $\mathrm{HCl}$, ultrapure water, and a small amount of sample, before filtering the bulk of the sample. Subsamples were collected in cleaned $30 \mathrm{~mL}$ or $500 \mathrm{~mL}$ HDPE bottles and acidified to $\mathrm{pH} 2$ with QD $\mathrm{HCl}$ before storage.

\subsection{Meltwater incubation experiment}

Incubation of meltwater was carried out at the Ny-Ålesund research labs in order to determine how $\mathrm{dFe}$ changed over time and to investigate the role of light and DOC on $\mathrm{dFe}$. Five liters of meltwater were collected at the NVE station by pole sampling from the main channel of the Bayelva River. These samples were filtered and homogenized, then $1 \mathrm{~L}$ was added to each of four $2 \mathrm{~L}$ acid-cleaned PTFE-lined plastic bags, sealed with a PTFE plastic rod sealer, and incubated on an exterior balcony. Two incubations were performed in the dark and another two incubations were exposed to natural sunlight, which was visible 24 hours a day. Samples were exposed to ambient temperature fluctuations $\left(0-6{ }^{\circ} \mathrm{C}\right)$. From each sample bag, $100 \mathrm{ml}$ subsamples were taken on days $0,2,6,8$, and 13 , filtered, and stored for analysis of dissolved Fe and DOC. 
Dissolved iron concentrations were analyzed by ICPMS after single-batch

211 extraction onto a nitrilotriacetate resin (NTA, Qiagen) according to the procedures of

212 Lee et al. (2011). Briefly, samples were spiked with an enriched ${ }^{54} \mathrm{Fe}$ solution,

213 oxidized with $\mathrm{H}_{2} \mathrm{O}_{2}$, and extracted onto $\sim 100$ clean NTA resin beads. After separating

214 Fe from other ions on the NTA resin, samples were reconstituted in $0.5 \mathrm{M} \mathrm{HNO}_{3}$ for

215 analysis on a multi-collector ICPMS (Neptune, Thermo) at East China Normal

216 University. The Neptune was operated in high-resolution mode with a minimum

217 resolution of 6000 in order to separate ${ }^{54} \mathrm{Fe}$ and ${ }^{56} \mathrm{Fe}$ beams from ${ }^{40} \mathrm{Ar}^{14} \mathrm{~N}$ and ${ }^{40} \mathrm{Ar}^{16} \mathrm{O}$

218 interferences, respectively. Three replicates from each $30 \mathrm{ml}$ subsample were

219 prepared for analysis, and in rare cases where the three replicates did not agree

220 another 3 replicates were prepared. The typical procedural blank was $0.15 \mathrm{nM}$, with a

221 detection limit of $\sim 0.12 \mathrm{nM}$ (based on three-times the standard deviation of the

222 procedural blank). Accuracy of the method was tested by analysis of three SAFe open

223 ocean intercalibration samples, and our measurements compared favorably with the

224 consensus values (provided by Ken Bruland, April, 2013). Our measured Fe

225 concentrations for SAFe S, SAFe D1 and SAFe D2 were $0.094 \pm 0.019,0.68 \pm 0.07$

226 and $0.94 \pm 0.07 \mathrm{nM}$ compared to consensus values of $0.094 \pm 0.008,0.70 \pm 0.03$ and

$2270.95 \pm 0.02 \mathrm{nM}$, respectively. Measurements of two high concentration certified

228 reference materials (both NRC, Canada) also compared favorably: estuarine water

229 SLEW-3 $(10.4 \pm 0.2$ vs $10.2 \pm 1.2 \mathrm{nM})$ and river water SLRS-5 $(1.25 \pm 0.10$ vs $1.62 \pm$ 
$230 \quad 0.12 \mu \mathrm{M}$ ). We suspect that the relatively lower accuracy of our technique for samples

231 with higher $\mathrm{Fe}$ concentrations is due to low spike/sample ratios. Therefore, Fe 232 concentrations for meltwater samples with high concentrations of dFe were obtained 233 from double-spike Fe isotope analyses (see below).

$2.5 \mathrm{Fe}$ isotope analysis

Iron stable isotope analyses were carried out using a double-spike technique

237 according to previously published methods (Conway et al., 2013). Briefly, samples

238 were spiked with an iron double spike consisting of roughly equal amounts of ${ }^{57} \mathrm{Fe}$

239 and ${ }^{58} \mathrm{Fe}$ at a sample:spike ratio of 1:2. Samples were then dried down in clean PFA

240 vials, reacted with $200 \mu \mathrm{L}$ each of clean concentrated $\mathrm{HNO}_{3}$ and $\mathrm{H}_{2} \mathrm{O}_{2}$ (Aristar, VWR)

241 to dissolve any organic material, and dried down again. Samples were then purified

242 by anion exchange chromatography according to methods developed for marine

243 particulate Fe (Revels et al., in press). Samples were first reconstituted in $0.2 \mathrm{~mL} 10$

$244 \mathrm{M} \mathrm{HCl}$ and $0.001 \mathrm{M} \mathrm{H}_{2} \mathrm{O}_{2}$, then loaded onto $135 \mu \mathrm{L}$ AG-MP1 resin. After rinsing

245 with $0.5 \mathrm{~mL} 10 \mathrm{M} \mathrm{HCl}$ and $0.001 \mathrm{M} \mathrm{H}_{2} \mathrm{O}_{2}$, iron was eluted from the resin with $0.8 \mathrm{~mL}$

$2461 \mathrm{M} \mathrm{HCl}$. The eluent was then dried down and reconstituted in $2 \mathrm{~mL} 0.1 \mathrm{M} \mathrm{HNO}_{3}$ for

247 isotopic analysis on a Neptune multi-collector ICPMS at the University of South

248 Carolina Center for Elemental Mass Spectrometry. In addition to stable isotope $\left(\delta^{56} \mathrm{Fe}\right)$

249 data, the double spike method also allowed for the calculation of ultra-precise Fe 250 concentration data for all Bayelva River samples. 
$252 \quad 2.6$ Analysis of other physical and chemical parameters

253 Temperature, $\mathrm{pH}$, dissolved oxygen (DO), and salinity were measured in situ with

254 a WTW multiline F/sets3 multi-parameter probe. Total suspended material (TSM)

255 was determined by filtering onto pre-weighed Whatman GF/F filters, which were then

256 freeze dried and reweighed. Dissolved organic carbon (DOC) was analyzed by the

257 high-temperature catalytic oxidation (HTCO) method with a Shimadzu TOC analyzer

258 (Model TOC-CPH) according to the methods of Wu et al. (2013). The method used

259 for determination of dissolved manganese $(\mathrm{dMn})$ is modified from the methods of 260 Resing and Mottl (1992), which determined dMn concentrations by leucomalachite 261 green-sodium periodate catalytic kinetic spectrophotometry (Wang et al., 2015).

262

263 3. Results

264

265 3.1 Bayelva River

266 3.1.1 Bayelva River transect

267 During both the 2012 and 2013 field seasons, samples were taken from three

268 stations along the Bayelva River on the same day (Fig. 2). In both years, the highest

$269 \mathrm{dFe}$ concentrations were observed in samples taken closest to the glacier output (734

$270 \mathrm{nM}$ in 2012 and $401 \mathrm{nM}$ in 2013) with decreasing concentrations downstream. During

2712012 , dFe was approximately twice as high at all three stations compared to 2013, 
272 though the rate of dFe loss was similar both years with a $71 \%$ decrease in $\mathrm{dFe}$

273 between HBR and NVE stations in 2012 and an 84\% reduction in dFe between the

274 same stations in 2013. Additionally, dFe was measured in two samples taken from

275 tributaries to the Bayelva River in 2012, with $226 \mathrm{nM}$ in a supraglacial tributary and

$276157 \mathrm{nM}$ in a tributary near NVE station.

277 A variety of other physical and chemical parameters were also measured along

278 the transect. Little variation of $\mathrm{pH}$ was observed, with an average $\mathrm{pH}$ of $8.23 \pm 0.41$ in

2792012 and $8.27 \pm 0.68$ in 2013. Dissolved oxygen (DO) increased slightly with distance

280 from the glacier during both years, from $12.6 \mathrm{mg} \mathrm{L}^{-1}$ at HBR to a supersaturated value

281 of $20.1 \mathrm{mg} \mathrm{L}^{-1}$ at NVE in 2012, and an increase from $12.5 \mathrm{mg} \mathrm{L}^{-1}$ to $15.3 \mathrm{mg} \mathrm{L}^{-1}$ at the

282 same stations in 2013. DOC and dMn both decreased away from the glacier in 2012,

283 from $275 \mathrm{nM}$ to $153 \mathrm{nM}$ for $\mathrm{dMn}$ and from $167 \mu \mathrm{M}$ to $98 \mu \mathrm{M}$ for DOC. TSM

284 increased $17 \%$ from $389 \mathrm{mg} \mathrm{L}^{-1}$ at station HBR to $455 \mathrm{mg} \mathrm{L}^{-1}$ at station MBR, then

285 decreased to a value of $115 \mathrm{mg} \mathrm{L}^{-1}$ at station NVE. Dissolved $\delta^{56} \mathrm{Fe}$ did not vary in

286 any systematic fashion along the transect, with all values between $-0.11 \%$ and $0.09 \%$. 

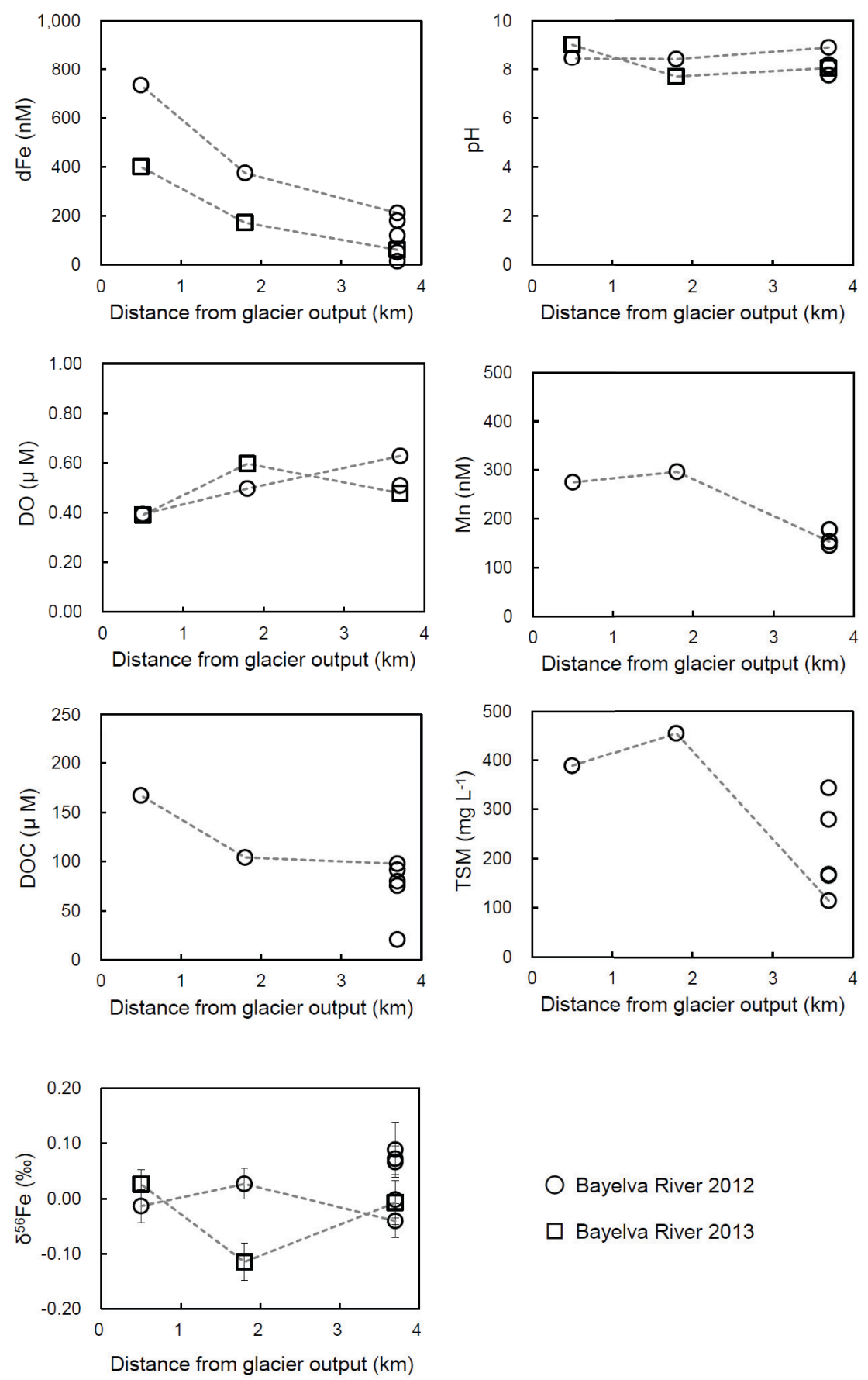

$\square$ Bayelva River 2013

Fig. 2. Dissolved $\mathrm{Fe}(\mathrm{dFe})$ concentrations, $\delta^{56} \mathrm{Fe}$ values, and ancillary parameters including $\mathrm{pH}$, dissolved Mn (dMn), dissolved oxygen (DO), dissolved organic carbon (DOC), and total suspended matter (TSM) in the Bayelva River. Open circles represent data from 2012 and open squares represent data from 2013. Dashed grey lines connect data from samples taken during the same day. 
NVE station.

302

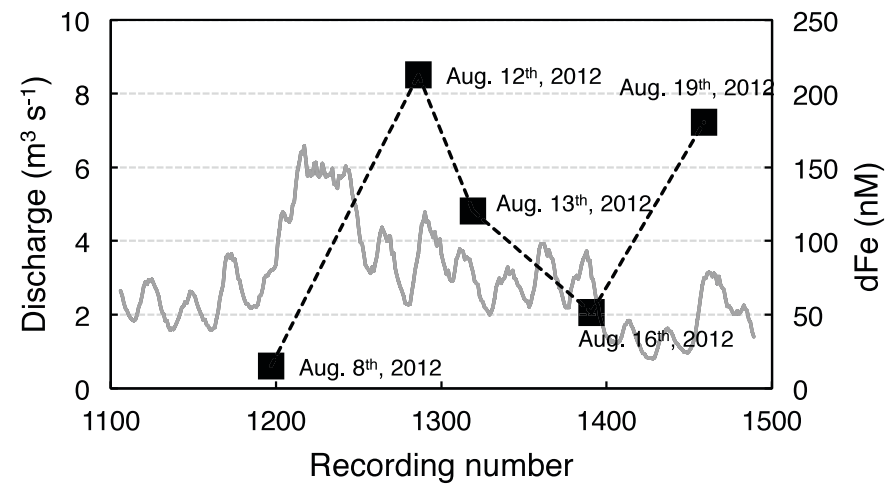

303 Fig. 3. Dissolved iron concentrations (open circles) and discharge (grey line) monitored at NVE station on the Bayelva River in August 2012. Sampling date for each dFe measurement is given beside dFe data symbols.

Dissolved Fe concentrations were measured at a variety of salinities in the 
310 (Fig. 4). Assuming that the average dFe concentration measured at the NVE station,

$311 \sim 300 \mathrm{~m}$ upstream from Kongsfjorden, represents the freshwater end-member (116

$312 \mathrm{nM}$ ), there is a significant loss of Fe immediately upon mixing of fresh and saline

313 waters, with $\mathrm{dFe}$ of $27.4 \mathrm{nM}$ at a salinity of $1.5, \mathrm{dFe}$ of $11.3 \mathrm{nM}$ at a salinity of 6.9 ,

314 and an average dFe of $4.7 \pm 1.6 \mathrm{nM}(\mathrm{n}=7)$ at salinities $\sim>10$.

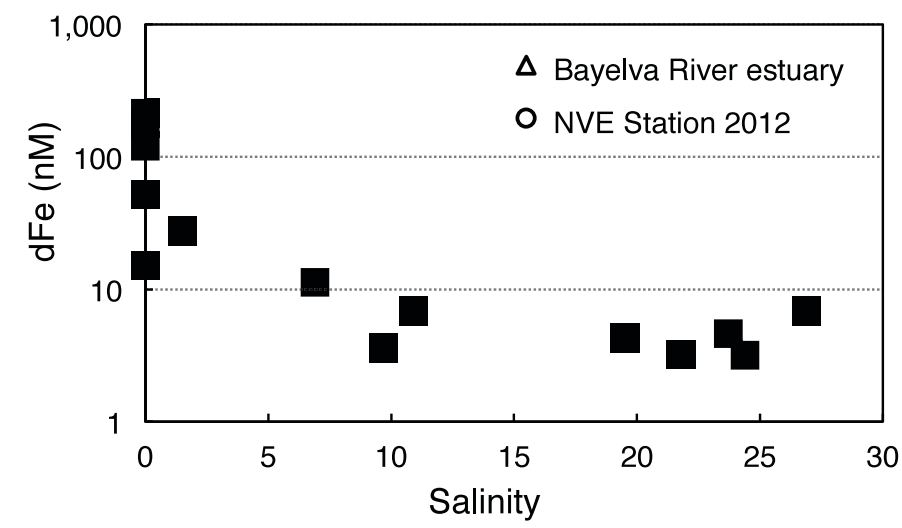

315

316 Fig. 4. Dissolved Fe (dFe) concentrations compared to salinity in Bayelva River estuary (triangles) and

317 in the Bayelva River roughly $300 \mathrm{~m}$ upstream of the estuary (circles).

3193.3 Freshwater incubations

320 Incubations of Bayelva River waters were performed for two weeks in both

321 natural light conditions and in the dark, during which time $\mathrm{dFe}$ and $\mathrm{DOC}$

322 concentrations were monitored (Fig. 5). dFe in filtered waters from the NVE station at

323 the beginning of the experiment (incubation day 0) was $15 \mathrm{nM}$. This decreased

324 sharply to $\sim 7 \mathrm{nM}$ by day 2 in both dark and light incubations. Subsequently, dFe

325 concentrations in the dark incubations remained relatively constant, decreasing only

$326 \sim 1 \mathrm{nM}$ over the next 12 days of the incubation experiment, with differences between 
327 the two replicate dark incubations within analytical error. In contrast, dFe in the light

328 incubations decreased further, to about $5 \mathrm{nM}$ by the end of the experiment. DOC also

329 decreased dramatically within the first 2 days of the experiment from $75 \mu \mathrm{M}$ at day 0

330 to $\sim 15 \mu \mathrm{M}$ at day 2 . Between days 2 and 12 there did not appear to be much further

331 loss of DOC, though it is possible that samples were contaminated during filtration,

332 especially considering the low DOC present. Nonetheless, the $\sim 75 \%$ loss of DOC at

333 the beginning of the experiment was observed in all four samples and therefore

334 appears robust.
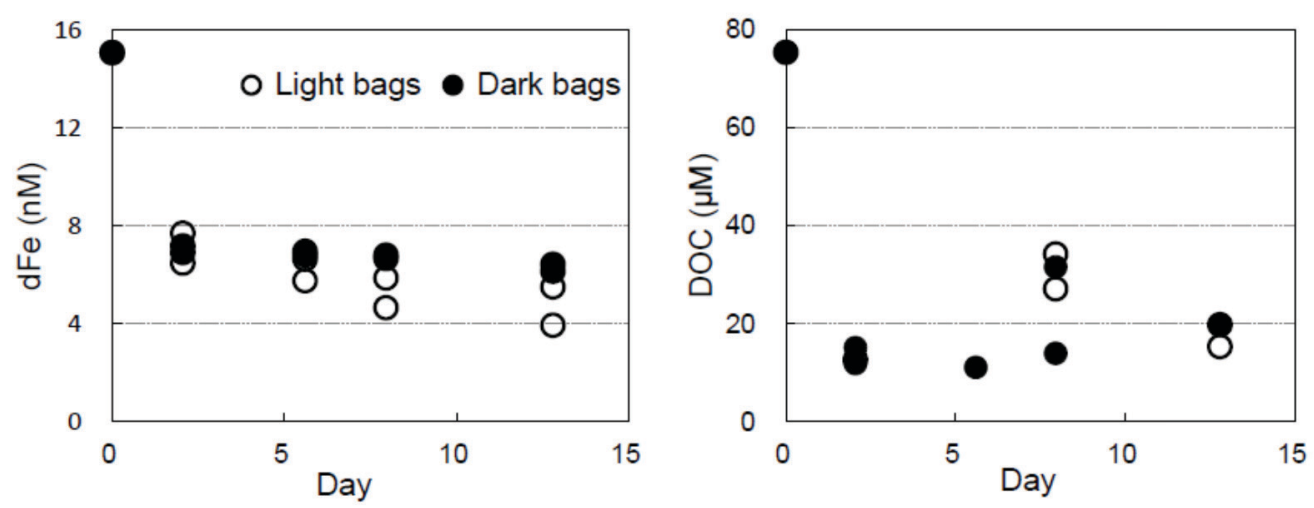

335

336 Fig. 5. Dissolved Fe and DOC concentrations in light and dark incubations in duplicates. Open circles

337 are bags incubated in daylight, while solid circles represent bags kept in the dark.

\section{Discussion}

A primary aim of this study is to investigate the transportation and transformation

341 of dFe between a glacial source and the ocean, via a glacial meltwater river, and to

342 evaluate the importance of glacial meltwaters as a source of Fe to the oceans. To do

343 so requires both a quantitative measure of the amount of dissolved $\mathrm{Fe}$ which is 
344 stabilized in glacial meltwaters, where it can ultimately be delivered to the oceans,

345 and an understanding of the chemical transformations by which Fe is lost from glacial

346 waters. Below we discuss both our observations about $\mathrm{Fe}$ concentrations in the

347 Bayelva River and estuary, and hypothesize about the processes responsible for Fe

348 precipitation or stabilization.

$350 \quad 4.1$ Sources of water and Fe to the Bayelva River

351 Though we regard the Bayelva River as being mostly closed to new inputs along

352 it's course to the ocean, there are likely small inputs from groundwater and tributary

353 streams. For example, Mn concentrations were $\sim 8 \%$ higher at the MBR station

354 compared to HBR, suggesting either rapid timescale variability in Mn output from the

355 glacier or input from hyporheic groundwater (Green et al., 2005). Inputs from longer

356 residence-time groundwater to the Bayelva are not thought to be significant (Nowak

357 and Hodson, 2013). During the sampling period, we did not observe any large

358 tributaries to the main stream of Bayelva River. dFe concentrations in the two

359 tributaries which we measured ( 200 nM) were not low enough to account for the loss

360 of Fe along the path of the Bayelva by dilution alone. Discharge data from many

361 different years has suggested that meltwater from Austre Brøggerbreen contributes

$362>50 \%$ of total discharge in Bayelva River (Hodson et al., 1998). We therefore

363 conclude that while lateral inputs of both water and Fe to the Bayelva River may

364 occur, they are not a dominant factor in $\mathrm{dFe}$ and cannot explain the dramatic $\mathrm{dFe}$ 
decrease observed downstream in the Bayelva River.

Several lines of evidence suggest that most dissolved Fe is quickly precipitated within hours after emerging from the glacier, but that a small fraction (4-7 nM) is present in a chemical form that is stable over a period of days to weeks. In both 2012 and 2013, Fe concentrations decreased markedly downstream in the Bayelva River

371 (Fig. 2). Estimates of river velocity suggest that water travels the entire $\sim 4 \mathrm{~km}$ from

372 the glacier to Kongsfjorden in 1 to 3 hours (Hodson et al., 2005), suggesting that the 373 half-life for $\mathrm{dFe}$ in the river is about an hour or less. While most of the $\mathrm{dFe}$ was 374 precipitated from river waters during this short transect, significant quantities 375 remained even in the samples taken downstream at the NVE station $(15-213 \mathrm{nM})$.

376 Considering that our first sampling site located at the highest accessible location was 377 still $\sim 0.5 \mathrm{~km}$ from the glacier output, our measurements of $\mathrm{dFe}$ and our estimates of 378 Fe loss in the proglacial environment represent likely minimum values. Incubation experiments also suggest that a small portion of glacial meltwater Fe 380 is present in a stable dissolved form, regardless of whether samples are exposed to 381 sunlight or not. When Bayelva River waters were incubated, a rapid loss of Fe was 382 observed over the first two days of the experiment. In the dark incubations, very little 383 additional Fe was lost from the dissolved phase. The rate of Fe loss from the dissolved 384 phase in the light incubations was also quite slow from days 2 to 12 , compared to 385 rates of Fe loss in the Bayelva River and during the first two days of incubation. The 
slight loss of Fe in the light incubations is consistent with the work of Shiller et al.

387 (2006), who found that photooxidization could destroy Fe binding organic ligands

388 leading to precipitation of Fe(III). We cannot rule out the possibility that the rapid

389 loss of dFe over the first two days was due to Fe adsorption to the PTFE bag lining,

390 though PTFE is not very surface reactive to either inorganic Fe oxyhydroxides or

391 organically bound Fe. Even if a significant amount of Fe was lost by adsorbing to the

392 bag walls, rather than by precipitation and removal during filtration, this may still

393 reflect a large pool of surface-reactive $\mathrm{Fe}$ in the Bayelva River that would be lost

394 either by precipitation or adsorption during transit or during flocculation upon mixing

395 with the estuary. The relative surface area in the incubation bags is not much different

396 from the surface area exposed within the stream bed. Thus, we expect that $\sim 4-7 \mathrm{nM}$

397 of Fe which remained dissolved in the incubation experiments would also remain

398 dissolved under natural conditions.

399 A similar pattern is observed in the Kongsfjorden estuary, with $\sim 90 \%$ of the

400 dissolved Fe present at the NVE station in the Bayelva River lost during the early

401 stages of estuarine mixing (based on an average $\sim 120 \mathrm{nM}$ dFe at the NVE station).

402 This amount of loss is similar to other, non-glacial river systems and mixing

403 experiments, where much of the riverine $\mathrm{Fe}$ is lost as the ionic strength of the waters

404 increase (Bergquist and Boyle, 2006; Buck et al., 2007; Dai et al., 1995; Krachler et

405 al., 2005; Laglera and van den Berg, 2009). Fe concentrations in the estuary were not

406 significantly different between salinities of 7 to $11(7.3 \pm 3.9 \mathrm{nM}, \mathrm{n}=3)$ compared to 
407 salinities of 19 to $27(4.4 \pm 1.5 \mathrm{nM}, \mathrm{n}=5)$. This suggests mixing of brackish water $(\mathrm{S}=$

408 7-11) with seawater ( $\mathrm{S}=34)$, both of which had Fe concentrations of about $5 \mathrm{nM}$, with

409 little loss or addition of Fe during mixing. During 2012 an endmember seawater

410 sample was collected from the mouth of the Kongsfjorden bay, where it enters the

411 Arctic Ocean, which contained $\sim 3 \mathrm{nM}$ dFe at a salinity of 34 (data not shown).

412 Considering together all incubation samples after 2 days of incubation, and all

413 estuarine samples at salinities $\sim>10$, we suggest that between $4 \mathrm{nM}$ and $7 \mathrm{nM}$ of

414 glacial $\mathrm{Fe}$ in the Bayelva River is stabilized in the dissolved phase $(5.8 \pm 1.4 \mathrm{nM}$,

$415 \mathrm{n}=20$ ). This represents roughly $1 \%$ of the $\mathrm{Fe}$ concentrations measured near to the 416 glacial outflow.

$418 \quad 4.3$ Mechanism of Fe precipitation

419 4.3.1 Chemical form of Fe in meltwaters

420 The high dissolved Fe concentrations observed near the glacial outlet may be

421 either truly dissolved chemical species $(<0.02 \mu \mathrm{m})$, or small particles which fall in the 422 size range typically described as colloidal or nanoparticulate. One possible 423 mechanism by which Fe may dissolve underneath the glacier or within the moraines 424 of the glacial forefield is by the formation of reduced, soluble Fe(II) from sulphide 425 oxidation, weathering, or microbial respiration (Wadham et al., 2013). Because 426 Austre Brøggerbreen is a cold-based glacier there will be a minimum of delayed 427 subglacial meltwater, though even in cold-based glaciers there can be temperate ice 
428 and thin films of water at the ice-rock interface (Raiswell and Canfield, 2012).

429 Observations of water chemistry in Bayelva River have suggested the meltwater does

430 have a subglacial signature during the late ablation season (Nowak and Hodson, 2014).

431 The oxidation half-life of Fe(II) in natural fresh water is typically seconds to minutes

432 (Davison and Seed, 1983), however Fe (II) may be stabilized by complexation with

433 organic ligands (Statham et al., 2012). While we do not observe consistently lower

434 dissolved oxygen concentrations near the glacier, we do observe high dissolved Mn

435 concentrations $(153-296 \mathrm{nM})$ that persist for $4 \mathrm{~km}$ downstream of the glacier output

436 (Fig. 2). Reduced Mn(II), like Fe(II), is easily water soluble while oxidized Mn(III) is

437 particle reactive, however the oxidation half-life of $\mathrm{Mn}$ is significantly longer than for

438 Fe (Morgan, 2005). Higher dissolved Mn concentrations near the glacier may

439 therefore be indicative of reducing conditions in subglacial waters. Dissolved Fe in

440 meltwaters could be comprised either of dissolved Fe(II), or of nanoparticulate Fe(III)

441 minerals formed after oxidation of the river waters. Alternatively, iron in the

442 dissolved fraction may be present as nanoparticulate minerals, such as the

443 schwertmannite, which can form directly under glaciers when oxic waters weather Fe

444 sulfides (Raiswell et al., 2009).

$446 \quad$ 4.3.2 Mechanism of Fe loss

447 The study of Fe isotopes can help to constrain the mechanism by which Fe is lost

448 from the dissolved phase. The average $\delta^{56} \mathrm{Fe}$ was statistically equivalent at stations 
450 there was no apparent relationship between $\mathrm{dFe}$ and $\delta^{56} \mathrm{Fe}$ in the Bayelva River.

451 Assuming that the Bayelva River is a closed system, the relationship between $\mathrm{dFe}$ and $452 \delta^{56} \mathrm{Fe}$ can be modeled by Rayleigh distillation as:

$$
\delta^{56} F e_{\text {river }}=\delta^{56} F e_{\text {glacier }}+\Delta \delta^{56} F e_{\text {precipitate-dissolved }} \cdot \ln (F)
$$

456 where $\delta^{56} \mathrm{Fe}_{\text {river }}$ is the $\mathrm{Fe}$ isotope composition measured in the Bayelva River, $457 \delta^{56} F e_{\text {glacier }}$ is the dissolved $\delta^{56} \mathrm{Fe}$ at the glacier output, $\Delta \delta^{56} F e_{\text {precipitate-dissolved }}$ is the 458 isotope effect of $\mathrm{Fe}$ precipitation, and $F$ is the fraction of $\mathrm{Fe}$ remaining in the 459 dissolved phase. Doing so, we find that all of the $\delta^{56} \mathrm{Fe}$ data can be fit with Rayleigh 460 distillation curves assuming that the process by which Fe precipitates fractionates Fe 461 isotopes by less than -0.05 to $+0.05 \%$ from a starting $\mathrm{dFe}$ of $700 \mathrm{nM}$ and a starting $462 \delta^{56} \mathrm{Fe}_{\text {glacier }}$ of $-0.02 \%$ (Fig. 6). Dissolved $\delta^{56} \mathrm{Fe}$ is also similar to the crustal average of 463 around $0.07 \%$ (Poitrasson, 2006), suggesting that Fe isotopes were not greatly 464 fractionated during dissolution under the glacier before entering the Bayelva River.

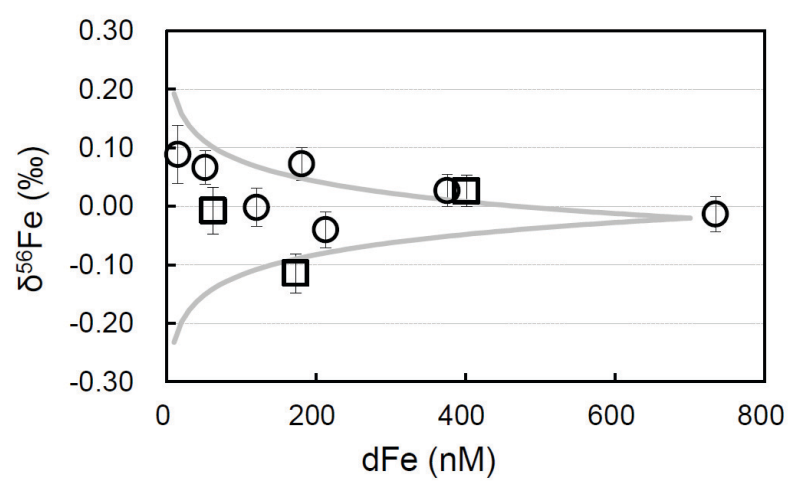


Fig. 6. $\delta^{56} \mathrm{Fe}$ versus $\mathrm{dFe}$ concentration. Open circles represent data from 2012, while open squares are

$\mathrm{dFe}$ and $\delta^{56} \mathrm{Fe}=-0.02 \%$.

In many natural environments, Fe precipitation occurs by processes that are associated with large $\mathrm{Fe}$ isotope fractionations, a pattern that is inconsistent with

473 Bayelva River $\delta^{56} \mathrm{Fe}$ measurements. For example, Fe(II) is roughly $3 \%$ lighter that $474 \mathrm{Fe}(\mathrm{III})$ at isotopic equilibrium (Johnson et al., 2002; Welch et al. 2003), and 475 environments where $\mathrm{Fe}(\mathrm{II})$ and $\mathrm{Fe}(\mathrm{III})$ are both present are generally characterized by 476 large variations in $\delta^{56} \mathrm{Fe}$ of up to several permil. Examples include reducing sediment 477 porewaters (Severmann et al., 2006; Severmann, et al., 2010), hydrothermal vents 478 (Bennett et al., 2009; Severmann et al., 2004), and submarine groundwaters (Rouxel 479 et al., 2008), all of which exhibit $\delta^{56} \mathrm{Fe}$ at least several permil different from the 480 crustal average. Non-redox chemical changes in Fe speciation are also typically 481 associated with large kinetic isotope effects. For example, a series of inorganic Fe(III) 482 precipitation experiments exhibited isotopic fractionations from -0.22 to $-2.12 \%$ with 483 an average $\delta^{56} \mathrm{Fe}$ of $-0.95 \%$ (Balci et al., 2006). Kinetic isotope effects associated 484 with the binding and unbinding of Fe to organics have not been well studied, but 485 organic complexation of Fe by the organic siderphore DFB leads to an equilibrium 486 isotope offset of $0.6 \%$ fractionation in $\delta^{56} \mathrm{Fe}$ compared to inorganic $\mathrm{Fe}$, suggesting 

larger (Dideriksen et al., 2008). We cannot rule out the possibility that Fe precipitation in the Bayelva River involves a change in Fe speciation associated with a very small kinetic or equilibrium isotope effect. However, we consider it more

491 likely that Fe speciation does not change during precipitation.

494 the aggregation of nanoparticulate/colloidal Fe. Complexation of Fe by organic 495 ligands is common in natural environments, and such complexes are known to keep 496 Fe(III) dissolved in solution (Rue and Bruland, 1995). Both dFe and DOC are present 497 at much higher concentrations close to the glacier, and concentrations of both 498 decrease downstream (Fig. 2, Fig. 7). However, given a DOC photodegradation rate 499 of $\sim 0.25 \mu \mathrm{M} \mathrm{h}^{-1}$ (Mostofa et al., 2007; Shiller et al., 2006) and the short water travel 500 time (1-3 h, Hodson et al., 2005), there should be minimal loss of DOC by 501 photodegration in the Bayelva River. Instead we presume that the DOC is lost 502 predominantly by adsorption onto particulates. This is supported by the finding that 503 particulate organic carbon increased by $\sim 80 \%$ during the transit from station HBR to 504 station NVE (Zhu et al., in prep), suggesting that DOC loss and dFe precipitation may 505 occur simultaneously. The relationship between DOC and dFe is not entirely linear 506 however, suggesting either that the organics which bind $\mathrm{Fe}$ are precipitated more 507 quickly than bulk DOC, or that dissolved Fe is not bound to organics. Alternatively, 
much of the dissolved $\mathrm{Fe}$ may be present as nanoparticulate/colloidal minerals.

509 Operationally, colloidal materials are those in the 0.02 to $0.4 \mu \mathrm{m}$ size range, meaning

510 that they can pass through a filter to be included in the dissolved phase but still have

511 relatively high molecular weights compared to most "truly dissolved" species.

512 Chemically, colloids are large enough that atoms on their interior do not chemically

513 interact with the environment. Thus, aggregation and precipitation of

514 nanoparticulate/colloidal Fe is a pathway by which Fe could leave the dissolved phase

515 without any significant change in Fe bonding environment. Considering the lack of

516 isotopic fractionation during Fe precipitation in the Bayelva River, we propose that

517 precipitation of nanoparticulate/colloidal Fe is the most likely pathway for the loss of

518 dissolved Fe. The suggestion that much of the dFe in Bayelva River meltwaters

519 occurs as nanoparticles/colloids matches similar findings from Greenland (Hawkings

520 et al., 2014) and Alaska (Schroth et al., 2011).

521
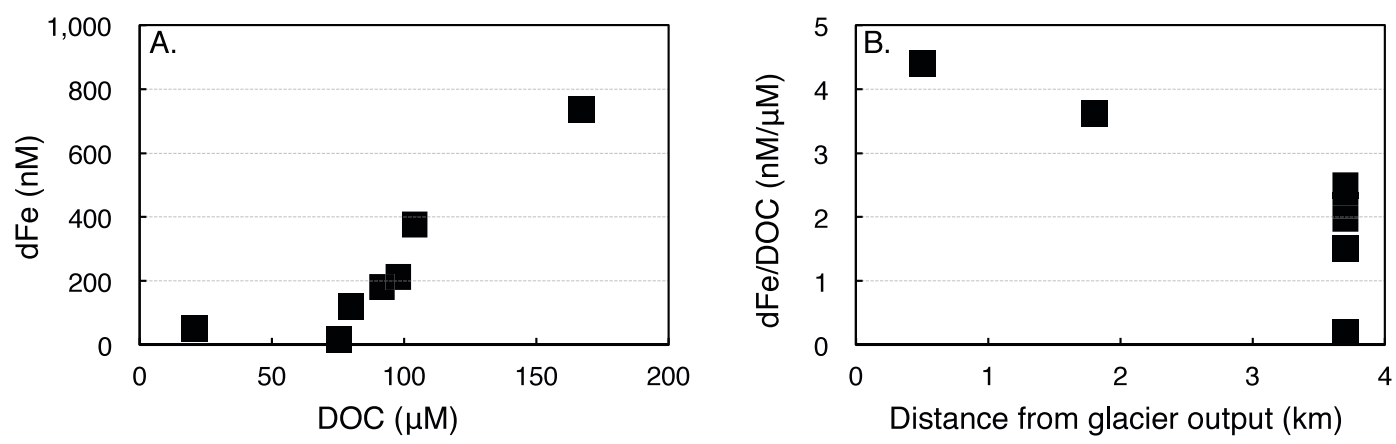

523 Fig. 7. A. dFe versus DOC in Bayelva River. B. dFe to DOC ratio versus distance from glacier output. 

average. The total range for glacial waters reported from previous studies is from a minimum of $20 \mathrm{nM}$ to a maximum of $9,950 \mathrm{nM}$, with an average concentration of $\sim 1000 \pm 1600 \mathrm{nM}$ for all published meltwater concentrations $(\mathrm{n}=110)$ (Bhatia et al.,

$531 \mathrm{dFe}$ concentration for all glacial river samples from this study was $233 \pm 218 \mathrm{nM}$ $532(\mathrm{n}=10)$, which is at the lower end of the global range. Some of this variability may be 533 driven by differences in sampling protocol. The highest previously reported $\mathrm{Fe}$ 534 concentrations were for samples filtered directly in the field (Bhatia et al., 2013), 535 while lower Fe concentrations were observed by Statham et al. (2008) and in this 536 study, where filtration occurred in the lab several hours after sampling. However, no 537 observable precipitate observed during filtration of samples in this study. Also, if such 538 rapid precipitation were occurring it would be consistent with our overall finding that 539 the half-life for $\mathrm{dFe}$ in glacial meltwater is quite short.

540 Crucially for estimating the flux of glacial Fe to seawater, we hypothesize that 541 dissolved Fe in the Bayelva River occurs in two very different forms. Most of the 542 dissolved Fe measured near the glacier outflow is precipitated within hours to days, 543 and does not enter the Kongsfjorden estuary where it might ultimately mix into the 544 North Atlantic. We propose that this Fe is predominantly Fe nanoparticles/colloids. A 545 second species of Fe, present at concentrations of 5-10 nM appears to be stable on 546 timescales of days to weeks. We propose that this portion of $\mathrm{Fe}$ is organically 

suggest that total dissolved Fe concentrations may be a much less important parameter than the concentration of Fe which is stabilized in the dissolved phase for long enough

550 to be mixed into the coastal ocean.

551 In contrast to previous studies, extrapolating the lower $\mathrm{dFe}$ concentrations found 552 in the Bayelva River to global glacial meltwaters would not support glaciers as being 553 an important source of Fe to the North Atlantic. Based on dFe concentrations of 3.7 $554 \mu \mathrm{M}$ in glacial meltwaters measured in Greenland, and assuming a 90\% loss of $\mathrm{dFe}$ 555 during estuarine removal processes, Bhatia et al. (2013) extrapolate to the $0.5 \mathrm{Tm}^{3} / \mathrm{y}$ 556 Greenland Ice Sheet runoff volume and predict an annual flux of $\sim 0.01 \mathrm{Tg}$ of 557 dissolved iron from the Greenland ice sheet to the North Atlantic. In contrast, 558 applying the same calculations to our average Bayelva River dFe concentration of 223 $559 \mathrm{nM}$, we would predict fluxes more than an order of magnitude lower $\left(6 \cdot 10^{-4} \mathrm{Tg} / \mathrm{y}\right)$. 560 Similarly, applying our $223 \mathrm{nM}$ to the global glacial meltwater discharge of $1.4 \mathrm{Tm}^{3} / \mathrm{y}$ 561 (Raiswell et al., 2006), we would calculate a global dFe input (before accounting for 562 estuarine removal processes) of $0.017 \mathrm{Tg} / \mathrm{y}$, which is insignificant compared to other 563 global Fe fluxes, calculated to be of the order of $\sim 1-100 \mathrm{Tg} / \mathrm{y}$ (Jickells et al., 2005). 564 Furthermore, the decrease in $\mathrm{dFe}$ concentration between our mean glacial runoff 565 samples $(223 \mathrm{nM})$ and concentrations measured in mid salinity estuarine waters (a 566 mean of $4.4 \mathrm{nM}$ over a salinity range of 19 to 27 ) suggests that the assumed $90 \%$ 567 attenuation of $\mathrm{dFe}$ due to estuarine removal processes may be an underestimate. If we 
were to extrapolate from the 'stabilized dFe' (Fe which is assumed to remain in the

569 dissolved phase following the increase in salinity as it is delivered to the ocean)

570 concentrations of 4-7 nM from the Bayelva River to Greenland, we would estimate a

571 glacial flux of dFe from the Greenland Ice Sheet of between $1.4 \cdot 10^{-4}$ and $2.8 \cdot 10^{-4}$

$572 \mathrm{Tg} / \mathrm{y}$, which is much smaller than the $0.07-0.7 \mathrm{Tg} / \mathrm{y}$ soluble Fe input estimated from

573 dust deposition models (Boyd et al., 2010, Fan et al., 2006).

574 However, there are several reasons why the dFe measurements from the Bayelva

575 River in Svalbard may not be globally representative. First, The Bayelva River

576 originates from a cold-base glacier where the subglacial processes may be very

577 different from larger ice sheets in Greenland and Antarctica (Nowak and Hodson,

578 2014). Second, there is large variability in glacial bedrock types, catchment size, and

579 meltwater residence time, and these factors can affect Fe concentration and speciation

580 in meltwaters (e.g. Hawkings et al., 2014). Third, we find that processing in the

581 proglacial environment has a large impact on Fe concentrations and speciation, and

582 considering that our first sample was taken $\sim 500 \mathrm{~m}$ from the outflow of the glacier

583 there might be much higher dFe in anoxic englacial meltwaters, which in Antarctica

584 and Greenland can be delivered directly into the ocean providing both soluble and

585 reactive nanoparticulate Fe (Raiswell and Canfield, 2012). Finally, even though we

586 observed precipitation of dissolved Fe, the Bayelva River may still be delivering high

587 quantities of reactive particulate $\mathrm{Fe}$ to the ocean. Phytoplankton may acquire $\mathrm{Fe}$

588 directly from such particles to support their growth (e.g. Thuróczy et al., 2012). 
589 Alternatively, reactive particulate Fe can be dissolved from within the sediments to 590 contribute Fe to the overlying water column (Wehrmann et al., 2014). While our data 591 add significantly to the global dataset on glacial Fe delivery to the oceans, and 592 provide some of the first measurements of Fe delivery from cold-based glaciers, 593 studies with greater spatial and temporal coverage will be needed to fully constrain 594 the possible importance of glacial Fe to the oceans.

595 While the concentration measurements made here cannot directly support glaciers 596 as a significant source of $\mathrm{Fe}$ to the North Atlantic, it is intruiging to note that the $\delta^{56} \mathrm{Fe}$ 597 data may be consistent with a large glacial input. Measurements of seawater dissolved $598 \delta^{56} \mathrm{Fe}$ from the North Atlantic show a distinct isotope signature in Upper Labrador Sea 599 Water (ULSW) near 0 to $+0.2 \%$ (Conway and John, 2014). This Fe isotope signature 600 was originally proposed to result from the interaction of ULSW with resuspended 601 oxic seafloor sediments. However this $\delta^{56} \mathrm{Fe}$ also matches our measurements of 602 glacial $\delta^{56} \mathrm{Fe}$, suggesting that glacial meltwater input may be contributing to North 603 Atlantic dFe.

604

605 5. Conclusions

606 Our data represent the first study of the transport of dissolved Fe in meltwaters all 607 the way from a glacier through a marine estuary (Fig. 8). In this study, a significant 608 loss of dFe in a glacial meltwater runoff was observed during transport through the 609 proglacial environment. In the Bayelva River, roughly $\sim 80 \%$ of Fe was lost between a 
610 station $0.5 \mathrm{~km}$ from the glacial outlet and a station $3.2 \mathrm{~km}$ further downstream. A

611 further $\sim 90 \%$ of the remaining $\mathrm{dFe}$ was lost in the Kongsfjorden estuary. Overall,

612 only $\sim 2 \%$ of the Fe output from the Austre Brøggerbreen Glacier was stabilized in the

613 estuary where it could eventually mix into the North Atlantic, excluding the possible

614 redissolution of particulate Fe within estuarine sediments. Based on analyses of

615 various physical and chemical parameters, especially DOC and $\delta^{56} \mathrm{Fe}$, we propose that

616 most of the dissolved Fe in the Bayelva River near the glacial output is in a

617 colloidal/nanoparticulate phase which rapidly precipitates from solution, while

618 roughly $4-7 \mathrm{nM}$ Fe is stabilized by complexation with organic ligands and can be

619 delivered into the Kongsfjorden estuary and eventually the North Atlantic. Given the

620 great variability in glacial Fe fluxes and glacial Fe geochemistry observed to date, our

621 results do not necessarily mean that glaciers are not an important source of Fe to the

622 oceans. However they do suggest that cold-based glaciers contribute relatively low

623 concentrations of $\mathrm{dFe}$, and that bedrock type, weathering intensity below the glacier,

624 and the character of the proglacial environment will all have a significant impact on

625 Fe concentration and speciation in meltwater, complicating efforts to extrapolate the

626 global flux of glacial Fe to the oceans from a limited number of measurements.

627 Anthropogenic climate change and global warming are predicted to greatly

628 impact the Arctic. Under such conditions, proglacial process will play an important

629 role in controlling the amount of Fe that is delivered to the oceans. Our study implies

630 that accurate estimation of glacial Fe fluxes depends both on sampling a wide variety 
631 of glacial locations, and on understanding more fully the processes which lead to the 632 precipitation and stabilization of Fe in proglacial environments.

633

634

635

636

637

638

639

640

641

642

643

644 innovation funding (2011KYYW02). John and Marsay were funded by the National

645 Science Foundation (NSF OCE-1334029). We would like to thank the Chinese

646 Antarctic and Arctic Administration of National Oceanic Bureau for the logistic

647 support for field sampling. We thank Zhongqiao Li and others for their efforts on the 
648 sample collection. We thank Yun Xue for her effort on maintaining the clean lab and 649 Neptune at East China Normal University.

650 


\section{References}

652

653 Achterberg, E.P., Moore, C.M., Henson, S.A., Steigenberger, S., Stohl, A., Eckhardt, 654 S., Avendano, L.C., Cassidy, M., Hembury, D., Klar, J.K., Lucas, M.I., Macey, 655 A.I., Marsay, C.M., Ryan-Keogh, T.J., 2013. Natural iron fertilization by the 656 Eyjafjallajökull volcanic eruption. Geophys. Res. Lett., 40, 921-926.

Balci, N., Bullen, T.D., Witte-Lien, K., Shanks, W.C., Motelica, M., Mandernack, 658 K.W., 2006. Iron isotope fractionation during microbially stimulated $\mathrm{Fe}(\mathrm{II})$

Bennett, S.A., Rouxel, O., Schmidt, K., Garbe-Schönberg, D., Statham, P.J., German, oxidation and Fe(III) precipitation. Geochim. Cosmochim. Acta 70, 622-639.

Bergquist, B.A., Boyle, E.A., 2006. Iron isotopes in the Amazon River system: 664 Weathering and transport signatures. Earth Planet. Sci. Lett. 248, 54-68. C.R., 2009. Iron isotope fractionation in a buoyant hydrothermal plume, $5^{\circ} \mathrm{S}$ Mid-Atlantic Ridge. Geochim. Cosmochim. Acta 73, 5619-5634.

Bhatia, M.P., Kujawinski, E.B., Das, S.B., Breier, C.F., Henderson, P.B., Charette, M.A., 2013. Greenland meltwater as a significant and potentially bioavailable source of iron to the ocean. Nat. Geosci. 6, 274-278.

668 Bogen, J., Bonsnes, T.E., 2003. Erosion and sediment transport in High Arctic rivers, 669 Svalbard. Polar Research 22, 175-189.

670 Boyd, P.W., Jickells, T., Law, C.S., Blain, S., Boyle, E.A., Buesseler, K.O., Coale, 

Levasseur, M., Owens, N.P.J., Pollard, R., Rivkin, R.B., Sarmiento, J., directions. Science 315, 612-617.

Boyd, P.W., Mackie, D.S., Hunter, K.A., 2010. Aerosol iron deposition to the surface ocean_Modes of iron supply and biological responses. Mar. Chem. 120, 128-143.

Bruland, K.W., Lohan, M.C., 2003. Controls of trace metals in seawater. (Holland, H.D., Turekian, K.H. Eds.) Treatise on Geochemistry (Vol. 6, p. 7800). Elsevier.

Buck, K.N., Lohan, M.C., Berger, C.J.M., Bruland, K.W., 2007. Dissolved iron speciation in two distinct river plumes and an estuary: Implications for riverine iron supply. Limnology and Oceanography 52, 843-855.

Conway, T.M., John, S.G., 2014. Quantification of dissolved iron sources to the North Atlantic Ocean. Nature 511, 212-215

Conway, T.M., Rosenberg, A.D., Adkins, J.F., John, S.G., 2013. A new method for precise determination of iron, zinc and cadmium stable isotope ratios in seawater

Dai M.H., Martin, J.M., 1995. First data on the trace metal level and behavior in two major Arctic river/estuarine systems ( $\mathrm{Ob} \&$ Yenisey) and in the adjacent Kara Sea, Earth Planet. Sci. Lett. 131, 127-141.

691 Davison, W., Seed, G., 1983. The kinetics of the oxidation of ferrous iron in synthetic 
693 Death, R., Wadham, J.L., Monteiro, F., Le Brocq, A.M., Tranter, M., Ridgwell, A., 694 Dutkiewicz, S., Raiswell, R., 2014. Antarctic ice sheet fertilises the Southern 695 Ocean. Biogeosciences 11, 2635-2643.

696 Dideriksen, K., Baker, J.A., Stipp, S.L.S., 2008. Equilibrium Fe isotope fractionation 697 between inorganic aqueous $\mathrm{Fe}(\mathrm{III})$ and the siderophore complex, 698 Fe(III)-desferrioxamine B. Earth Planet. Sci. Lett. 269, 280-290.

Elrod, V.A., Berelson, W.M., Coale, K.H., Johnson, K.S., 2004. The flux of iron from 700 continental shelf sediments: A missing source for global budgets. Geophys. Res. Lett. 31, L12307, doi:10.1029/2004GL020216.

Escoube, R., Rouxel, O.J., Sholkovitz, E., Donard, O.F.X., 2009. Iron isotope 703 systematics in estuaries: The case of North River, Massachusetts (USA). ocean. Geophys. Res. Lett. 33, L07602, doi:10.1029/2005GL024852.

707 Fantle, M.S., DePaolo, D.J., 2004. Iron isotopic fractionation during continental 708 weathering. Earth Planet. Sci. Lett. 228, 547-562.

709 Gerringa, L.J.A., Alderkamp, A.C., Laan, P., Thuroczy, C.E., De Baar, H.J.W., Mills, 710 M.M., van Dijken, G.L., van Haren, H., Arrigo, K.R., 2012. Iron from melting 711 glaciers fuels the phytoplankton blooms in Amundsen Sea (Southern Ocean): Iron 712 biogeochemistry. Deep-Sea Res. Part II 71-76, 16-31. 
713 Green, W.J., Stage, B.R., Preston, A., Wagers, S., Shacat, J., Newell, S., 2005.

714 Geochemical processes in the Onyx River, Wright Valley, Antarctica: Major ions, 715 nutrients, trace. Geochim. Cosmochim. Acta 69, 839-850.

716 Hagen, J.O., Kohler, J., Melvold, K., Winther, J.G., 2003. Glaciers in Svalbard: mass 717 balance, runoff and freshwater flux. Polar Res. 22, 145-159.

718 Hawkings, J.R., Wadham, J.L., Tranter, M., Raiswell, R., Benning, L.G., Statham, 719 P.J., Tedstone, A., Nienow, P., Lee, K., Telling, J., 2014. Ice sheets as a 720 significant source of highly reactive nanoparticulate iron to the oceans. Nat Commun 5.

Hodson, A.J., Gurnell, A.M., Washington, R., Tranter, M., Clark, M.J., Hagen, J.O., 1998. Meteorological and runoff time-series characteristics in a small, high-Arctic glaciated basin, Svalbard. Hydrological Processes 12, 509-526.

Hodson, A., Tranter, M., Gurnell, A., Clark, M., Hagen, J.O., 2002. The hydrochemistry of Bayelva, a high Arctic proglacial stream in Svalbard. Journal of Hydrology 257, 91-114.

Hodson, A.J., Mumford, P.N., Kohler, J., Wynn, P.M., 2005. The High Arctic glacial ecosystem: new insights from nutrient budgets. Biogeochemistry 72, 233-256.

Laglera, L.M., van den Berg, C.M.G., 2009. Evidence for geochemical control of iron by humic substances in seawater. Limnology and Oceanography 54, 610-619.

Ilina, S.M., Poitrasson, F., Lapitskiy, S.A., Alekhin, Y.V., Viers, J., Pokrovsky, O.S., 2013. Extreme iron isotope fractionation between colloids and particles of boreal 
735 Jickells, T.D., An, Z.S., Andersen, K.K., Baker, A.R., Bergametti, G., Brooks, N., 736 Cao, J.J., Boyd, P.W., Duce, R.A., Hunter, K.A., Kawahata, H., Kubilay, N., 737 laRoche, J., Liss, P.S., Mahowald, N., Prospero, J.M., Ridgwell, A.J., Tegen, I., 738 Torres, R., 2005. Global iron connections between desert dust, ocean 739 biogeochemistry, and climate. Science 308, 67-71.

740 Johnson, C.M., Skulan, J.L., Beard, B.L., Sun, H., Nealson, K.H., Braterman, P.S., 741 2002. Isotopic fractionation between $\mathrm{Fe}(\mathrm{III})$ and $\mathrm{Fe}(\mathrm{II})$ in aqueous 742 solutions. Earth Planet. Sci. Lett. 195, 141-153.

743 Jungclaus, J.H., Haak, H., Latif, M., Mikolajewicz, U., 2005. Arctic-North Atlantic 744 interactions and multidecadal variability of the meridional overturning circulation. J. Clim. 18, 4013-4031.

746 Krachler, R., Jirsa, F., Ayromlou, S., 2005. Factors influencing the dissolved iron input by river water to the open ocean. Biogeosciences. 2, 311-315.

748 Krawczyk, W.E., Lefauconnier, B., Pettersson, L.E., 2003. Chemical denudation rates in the Bayelva Catchment, Svalbard, in the Fall of 2000. Physics and Chemistry of the Earth 28, 1257-1271.

751 Lam, P.J., and Bishop, J.K., 2008. The continental margin is a key source of iron to the HNLC North Pacific Ocean. Geophys. Res. Lett. 35, L07608, doi:10.1029/2008GL033294.

754 Lee, J.M., Boyle, E.A., Echegoyen-Sanz, Y., Fitzsimmons, J.N., Zhang, R.F., Kayser, 

single batch nitrilotriacetate resin extraction and isotope dilution inductively coupled plasma massspectrometry. Anal. Chim. Acta. 686, 93-103.

758 Moore, J.K., Doney, S.C., Glover, D.M., Fung, I.Y., 2002. Iron cycling and 759 nutrient-limitation patterns in surface waters of the world ocean. Deep-Sea Res. Part II-Top. Stud. Oceanogr. 49, 463-507.

761 Moore, J.K., Doney, S.C., and Lindsay, K., 2004. Upper ocean ecosystem dynamics GB4028,doi:10.1029/2004GB002220.

Morgan, J.J., 2005. Kinetics of reaction between $\mathrm{O}_{2}$ and $\mathrm{Mn}(\mathrm{II})$ species in aqueous

Mostofa, K.M.G., Yoshioka, T., Konohira, E., Tanoue, E., 2007. Photodegradation of solutions. Geochim. Cosmochim. Acta 69, 35-48. fluorescent dissolved organic matter in river waters. Geochemical J. 41, 323-331.

Nielsdottir, M.C., Moore, C.M., Sanders, R., Hinz, D.J., Achterberg, E.P., 2009. Iron limitation of the postbloom phytoplankton communities in the Iceland Basin. Glob. Biogeochem. Cycles 23, GB3001, doi:10.1029/2008GB003410.

Nowak, A., Hodson, A., 2013. Hydrological response of a High-Arctic catchment to changing climate over the past 35 years: a case study of Bayelva watershed, Svalbard. Polar Research 32, 19691, http://dx.doi.org/10.3402/polar.v32i0.19691

774 Nowak, A., Hodson, A., 2014. Changes in meltwater chemistry over a 20-year period 775 following a thermal regime switch from polythermal to cold-based glaciation at 
Parekh, P., Follows, M.J., Boyle, E., 2004. Modeling the global ocean iron cycle.

Poitrasson, F., 2006. On the iron isotope homogeneity level of the continental crust. Chemical Geology 235, 195-200.

Raiswell, R., 2011. Iceberg-hosted nanoparticulate Fe in the Southern Ocean: Mineralogy, origin, dissolution kinetics and source of bioavailable Fe. Deep Sea Research Part II: Topical Studies in Oceanography 58, 1364-1375.

Raiswell, R., Benning, L.G., Davidson, L., Tranter, M., Tulaczyk, S., 2009. Schwertmannite in wet, acid, and oxic microenvironments beneath polar and

Raiswell, R., Canfield, D.E., 2012. The iron biogeochemical cycle past and present. polythermal glaciers. Geology 37, 431-434.

791 Raiswell, R., Tranter, M., Benning, L.G., Siegert, M., De'ath, R., Huybrechts, P., Payne, T., 2006. Contributions from glacially derived sediment to the global iron (oxyhydr)oxide cycle: Implications for iron delivery to the oceans. Geochim. Cosmochim. Acta 70, 2765-2780.

795 Resing, J.A., Mottl, M.J., 1992. Determination of manganese in seawater using flow 796 injection analysis with on-line preconcentration and spectrophotometric detection. 
798

799

800

801

802

803

804

805

806

807

808

809

810

811

812

813

814

815

Revels, B. N., Ohnemus, D. C., Lam, P. J., Conway, T. M. \& John, S. G. The isotope signature and distribution of particulate iron in the north Atlantic ocean. Deep Sea Res. Part II Top. Stud. Oceanogr. doi:10.1016/j.dsr2.2014.12.004 (in press).

Rue, E.L., Bruland, K.W., 1995. Complexation of iron(III) by natural organic-ligands in the central North Pacific as determined by a new competitive ligand equilibration adsorpthive cathodic stripping cathodic stripping voltammetric method. Mar. Chem. 50, 117-138.

Rouxel, O., Sholkovitz, E., Charette, M., Edwards, K.J., 2008. Iron isotope fractionation in subterranean estuaries. Geochim. Cosmochim. Acta 72, $3413-3430$.

Saito, M.A., Noble, A.E., Tagliabue, A., Geopfert, T.J., Lamborg, C.H., Jenkins, W.J., 2013. Slow-spreading submarine ridges in the South Atlantic as a significant oceanic iron source. Nat. Geosci. 6, 775-779.

Schroth, A.W., Crusius, J., Chever, F., Bostick, B.C., Rouxel, O.J., 2011. Glacial influence on the geochemistry of riverine iron fluxes to the Gulf of Alaska and effects of deglaciation. Geophys. Res. Lett. 38, L16605, doi:10.1029/2011GL048367.

Severmann, S., Johnson, C.M., Beard, B.L., German, C.R., Edmonds, H.N., Chiba, H., Green, D.R.H., 2004. The effect of plume processes on the $\mathrm{Fe}$ isotope composition of hydrothermally derived Fe in the deep ocean as inferred from the 

$-76$.

Severmann, S., Johnson, C.M., Beard, B.L., McManus, J., 2006. The effect of early diagenesis on the Fe isotope compositions of porewaters and authigenic minerals in continental margin sediments. Geochim. Cosmochim. Acta 70, 2006-2022.

823 Severmann, S., McManus, J., Berelson, W.M., Hammond, D.E., 2010. The continental shelf benthic iron flux and its isotope composition. Geochim. Cosmochim. Acta 74, 3984-4004.

Shiller, A.M., Duan, S.W., van Erp, P., Bianchi, T.S., 2006. Photo-oxidation of dissolved organic matter in river water and its effect on trace element speciation. Limno. Oceanogr. 51, 1716-1728.

Smith, K.L., Robison, B.H., Helly, J.J., Kaufmann, R.S., Ruhl, H.A., Shaw, T.J., and Biological Enrichment in the Weddell Sea. Science 317, 478-482.

832 Statham, P.J., Jacobson, Y., van den Berg, C.M.G., 2012. The measurement of 833 organically complexed FeII in natural waters using competitive ligand reverse titration. Anal. Chim. Acta 743, 111-116.

835 Statham, P.J., Skidmore, M., Tranter, M., 2008. Inputs of glacially derived dissolved 836 and colloidal iron to the coastal ocean and implications for primary productivity. Glob. Biogeochem. Cycle 22. GB3013, doi:10.1029/2007GB003106.

838 Stolpe, B., Guo, L., Shiller, A., Hassellov, M., 2010. Size and composition of 

and the northern Gulf of Mexico as characterized by flow field-flow fractionation. Mar. Chem. 118, 119-129.

Tagliabue, A., Bopp, L., Dutay, J.C., Bowie, A.R., Chever, F., Jean-Baptiste, P., Bucciarelli, E., Lannuzel, D., Remenyi, T., Sarthou, G., Aumont, O., Gehlen, M., Jeandel, C., 2010. Hydrothermal contribution to the oceanic dissolved iron inventory. Nat. Geosci. 3, 252-256.

Thuróczy, C.-E., Alderkamp, A.-C., Laan, P., Gerringa, L.J.A., Mills, M.M., Van Dijken, G.L., De Baar, H.J.W., Arrigo, K.R., 2012. Key role of organic complexation of iron in sustaining phytoplankton blooms in the Pine Island and Amundsen Polynyas (Southern Ocean). Deep Sea Research Part II: Topical Studies in Oceanography 71-76, 49-60.

851 Wang, Z.W., Ren, J.L., Liu, S.M., 2015. Determination method of dissolved manganese in natural water by catalytic kinetic spectrophotometry. Marine Environmental Science. (accepted manuscript, in Chinese)

Wadham, J.L., De'ath, R., Monteiro, F.M., Tranter, M., Ridgwell, A., Raiswell, R., Tulaczyk, S., 2013. The potential role of the Antarctic Ice Sheet in global biogeochemical cycles. Earth and Environmental Science Transactions of the Royal Society of Edinburgh 104, 55-67.

858 Wehrmann, L.M., Formolo, M.J., Owens, J.D., Raiswell, R., Ferdelman, T.G., 859 Riedinger, N., Lyons, T.W., 2014. Iron and manganese speciation and cycling in 
860 glacially influenced high-latitude fjord sediments (West Spitsbergen, Svalbard):

861 Evidence for a benthic recycling-transport mechanism. Geochim. Cosmochim. $862 \quad$ Acta $141,628-655$.

863 Welch, S.A., Beard, B.L., Johnson, C.M., Braterman, P.S., 2003. Kinetic and 864 equilibrium $\mathrm{Fe}$ isotope fractionation between aqueous $\mathrm{Fe}(\mathrm{II})$ and 865 Fe(III). Geochim. Cosmochim. Acta 67, 4231-4250.

866 Wu, Y., Bao, H.Y., Unger, D., Herbeck, L.S., Zhu, Z.Y., Zhang, J., Jennerjahn, T.C., 867 2013. Biogeochemical behavior of organic carbon in a small tropical river and 868 estuary, Hainan, China. Cont. Shelf Res. 57, 32-43.

869 Wu, J.F., Boyle, E., Sunda, W., Wen, L.S., 2001. Soluble and colloidal iron in the 870 olgotrophic North Atlantic and North Pacific. Science 293, 847-849. 